\title{
The Geographical and Socio-Cultural Aspects of the Minority of Ukrainians in Romania
}

\author{
Viorica Banciu, Remus Eugen Földvari, and Bianca Dana Albuţ
}

\begin{abstract}
Migrations have been seen throughout ancient and modern history. This mass movement represents a last resort to hardships that people endure in their own country. Like many other peoples many Ukrainians have seen in migration the best solution to the historical context they were undergoing.

Some of them chose as their new home, primarily, the region of Maramures in the North of Romania. Most of the emigrants, bought land, settled down, established families and communities and have been peacefully coexisting with the Romanian population.
\end{abstract}

Index Terms-Continuation hardships, migration, new beginning, peaceful coexistence.

\section{INTRODUCTION}

There is a saying in Romanian that goes like this: „Always be good with your neighbor because, when you are in need, the neighbor is the one living closest to you". In other words, in term of space, it is easier to reach a neighbor living close by than a brother living further away. This is the case with most of the Romanians living near the border areas of Romania. It is a known fact that neighbors learn from each-other, borrow certain ways of life and adopt others in order to naturally coexist. Such a case is that of the Ukrainians living north of Romania and those living within the boundaries of Romania.

The Objectives of the Paper:

- To popularize Ukrainian traditions in Romania;

- To show the link that forms between people of different origin living in the same geographical space;

- To show the transition from the old laic traditions to the new and more modern artistic events.

\section{THE MigRATION OF THE UKRAINIANS AND THEIR ADVERSITIES}

To understand the reasons why many Ukrainians chose to come and live in Romania, one should take a short look at the history of their migration. There have been several historical treaties about this topic during the last two centuries. Among them, one should remind the work of the economist and politician Vikentie Sandor entitled Zakarpatia-historical sources beginning with the IX-th century and up to the year 1920, the work of Hungarian politician Hevesy Andre entitled

Manuscript received January 27, 2013; revised March 28, 2013.

Viorica Banciu is with the University of Oradea at the Faculty of Socio-Humanistic Sciences, the Department of Sciences of Education (e-mail: myconferences18@gmail.com).

Remus Eugen Földvari is with the University of Oradea in Geography (e-mail: remusfoldvary @yahoo.com).

Bianca Dana Albuţ is with the University of Oradea in Sociology.
Nationalitier in Hungary, that of I. Perene entitled From the History of Ukrainians in Subcarpathia, 1848-1914, Ion Lotrean's work The Monography of Banat, volume one being entitled Inhabitants and communes in Banat, 1935, Petru Câmpeanu's work From the History of the Copăcele inhabitants, in 1987 and The culture and habits of the Ukrainians living in Carass-Severin county (this being his diploma paper which was given the qualifying of Very good by Vasile Ştefanic University in Ivano - Frankovks, Ukraine), Ivan Liber's The Wedding of the Copăcele inhabitants, and several other magazine articles [1].

\section{Settling Down AND Forming Communities}

All these documents present the situation of the Ukrainians in their own country and the reasons some of them had in order to live it. The first Romanian region that became home for these emigrants was the Maramureş. From there, they continued to move further south, going as far as the Banat area and the south of Romania. Among the main reasons for Ukrainians to leave their native lands and move somewhere else were, according to scholars, poverty, the feeling of being marginalized, the threat against their ethnic belonging, famine and others. The above mentioned works give clear numbers regarding the ownership of the land in Subcarpathia. Thus, from the 31.000 lanţe ( 1 lanţ $=0.58$ ha) $62.1 \%$ belonged to Hungarians, $18.9 \%$ belonged to the Jewish population, $14.3 \%$ belonged to the Germans, $3 \%$ to Romanians and $0.75 \%$ to the Slovakian and Ukrainian populations. We further learn that, according to Hevesy Andre in his work Nationalitier in Hungary, London 1919, 70.000 families represented the class that owned the lands while 7 million people didn't own even a patch of land [1]. Eduard Egan mentions that the lands were taken from the peasants, their pastures, their hay fields and even those lands that were collective property. Being robbed of their lands, these peasants lived in utter poverty, some, not eating meat or eggs the whole year round, only a little milk and some rye bread on holidays. Some of them didn't even own the livestock, the grain or hay on the lands that they work. Anyone can consider all these as reasons, for those living in such harsh conditions, to want to leave. Many of them have simply taken their families and left. Some of them settled down when being able to buy land, others got married, many found work and built homes. The main reason, however, was hunger. After agreements between land owners and emigrants, the latter came to these regions, bought plots of lands. At first, only the men came in seek of work, but, after such agreements, whole families came, bringing with them all their savings and livestock.

Few, at first, the Ukrainians started building houses, buy 
tools to work the land, establishing little by little settlements. In time, they built churches and mills, and these communities grew. When the old manors were sold, they were divided equally, according to the quality of the land, among the settlers. Each owner received a title deed and became officially his own master. Some of them borrowed money from the bank and had to pay it back twice a year. Because of the war, many families were unable to pay, since the men were on the front. After pleads, The Ministry of War in Hungary requested the pursuance of the bank to stop for these debtors until the ending of the war. After The Great Unification in December the first 1918, the Government of Romania cancelled all these debts. Settlements grew and flourished. People could think about happier moments, reviving their traditions and customs from back home for their new home. After the Second World War, after many dead, wounded people and broken families, these people, just like the entire country, started to rebuild their lives. They were able to graduate schools and to get jobs. With this money, they built new houses, and the communities grew. Schools were built, bakeries, mayorages, new roads, electricity was brought to remote villages, in other words, prosperity.

\section{UKRAINIAN MINORITY - HISTORICAL AND GEOGRAPHICAL ASPECTS}

Ukrainian minority in Romania is settled in the northern part of the country's historical Romanian provinces of Moldova and Maramureş, Timiş, and Dobrogea being less than $1 \%$ of the population, its development is done in parallel with the Romanian majority. Ukrainians settled in compact villages, with a majority Ukrainian and towns where the population is a minority. The number of this population was much higher in Romania until World War II when the country had bigger surface. After this episode in the history of Europe and of the whole world, the North-Eastern and Eastern space of Romania was occupied by the former Soviet Union and the Ukrainian population was incorporated in the state, and then, after 1990, with the fragmentation of the great communist state, the territory returned to Ukraine

The oldest Ukrainian settlements in the country are located in northern Moldavia and Maramureş in the neighborhood massif of Ukrainian ethnolinguistic space. Linguistic and archaeological evidence shows that the eastern Slavic population settled in these parts since the late sixth century, living with indigenous Romanian population, while most of the villages inhabited by Ukrainians today are mentioned in ancient historical documents (Slavonic in Moldova and Latin Hungarian Maramureş) XIV century and the fifteenth century. The oldest Ukrainian settlements in the country are located in northern Moldavia and Maramureş in the neighborhood massif of Ukrainian ethno linguistic space. Linguistic, cultural and spiritual Ukrainians in northern Maramures and Moldova were established and maintained by a continuous ethnic admixture of Carpathia, Galicia and Bukovina Pocutia.

Huţuluii (called "huţani" by Romanian) are those living in the mountainous area of Bukovina upper river valleys Suceava, Moldova, Moldova and Bistrita Aurie. Come here since the eighteenth century found favorable conditions to practice their traditional occupations: grazing, livestock, forestry work, rafting, found a large number of villages and hamlets they live today. Hutsuls speech dialects akin to the Ukrainian Carpathians and Bucovina which in turn are part of the Ukrainian language in common. Famous horse breeders (they have won just one race horse), Hutsul are also masters at making and decorating wooden objects, leather, horn, in weaving and embroidery. Painting Easter eggs (usually grown especially in villages Ulma, Brodina, Breaza, Moldova) brought them international fame [2].

Ukrainian settlement in Dobrogea (Danube Delta and surrounding areas) is related to some of the most tragic moments in the history of Ukraine: destroying, in 1775, the Tsarina of Russia, Catherine II, the Zaporozhian SICE, secular cradle of the aspirations of independence and freedom of the Ukrainian people. To save retaliation, about 8,000 Zaporozhian Cossacks are established with explicit prior approval of the High Porte, in the Danube Delta. To the realm of salvation, populous the beginning of Cossacks, moving up in the second half of the nineteenth century, groups of peasants from the southern regions of Ukraine to escape serfdom and tsarist army recruitment. They founded villages, built churches and mainly dealing with agriculture, fishing, hunting and farming. To distinguish their Russian neighbors, Lipovani locals call "haholi".

Ukrainian community in Banat, located in several villages in the Lugoj, Caransebes and Arad, was formed mainly between 1908-1918 by colonization of areas landowning offered for sale by their owners Germans and Hungarians, located in the south of the Empire Austro-Hungarian Empire then. Ukrainian settlers who bought plots of land and poor came from the highlands of Transcarpathia, in the right places located in Tisa, and others, in smaller numbers, Hutsuls area of Bukovina. Their exodus continued after 1918.

In the last hundred years the population of Ukrainian origin on the Romanian territory has remained constant, homogeneous phenomenon identical to the Romanian majority population. And now the Romanian territories keep tradition, with large families with many children compared to the rest of the country where, in many cases, families have only one child. Without being forced in any way or subjected to brutal processes of denationalization, Ukrainian population in Romania was able to preserve their language, traditions, customs and clothing [3].

\section{CARRYING ON THE TRADITIONS}

Even if people have evolved and have embraced new and more modern ways of life, the old traditions have not been forgotten. Their living among the Romanian populace didn't make them forget their ways, even if they have enriched them with new, imported ones. Folk fact that any oral work, "insofar as it is based on previous hearings, mandatory relate to a particular tradition, and to the extent that opens onto subsequent hearings, defines itself as tradition". [4] We can talk, if Ukrainian community, developing a tradition of contact between the two cultures occupying the same geographical area. It is impossible to imagine that living close to someone, day by day, one would not be influenced, even to 
the tiniest degree. Such is the case with all minorities in Romania. They have learnt from the Romanians and vice versa. Minorities preserve their language, arts, religion and certain ancient customs. But these customs can be borrowed and appropriated. The easiest way is through marriage, in mixed families. The language of the new country would be learnt in order to naturally coexist with the native populace. Being together in certain events, new customs would be learnt, old ways would be molded into new ones. Among these we can remind the wedding celebrations which still encompass the habits and customs brought from the places of birth-the threading of the flag from brightly colored ribbons, which are specific to the Ukrainian folk costumes, in alternation with ivy twigs, for the completion of which many young people took part-the horas organized on holidays or on Sundays, when there was no fasting periods, where many musicians took part and which naturally involved dancing. The artistic activities were organized by school masters or teachers together with their pupils, celebrating, even today, the winter holidays The Birth of God, The New Year, the Epiphany.

Ukrainian customs have been greatly influenced by the Christian religion, which has the most practitioners in the country. In the preserving of the old ways and habits the elders had a very important part, teaching their grandchildren. The tradition of Easter egg dyeing, pîsankî, is very old in Ukraine. People used wax to make different shapes and contours, then, they applied the color to dye them. After the dyeing the wax is removed and the contours are clear. Some say that this tradition is more than a thousand years old.[5]

Other habits and traditions are: spring traditions like Tânjaua, Udătorul, Easter habits, Ruptul sterpelor-separation of the barren ewes / Sâmbra oilor-Sambra sheep, Armindenul, summer traditions like The Fairies-Sânzienele, St. Elias-St. Ilie, harvesting traditions, autumn traditions like şezătorile-evening sitting of village women, clăcile-group work, Indreiu, winter traditions like carol singing, Viflaimul/herods, Constantinul-The Constantine, Steaua-The Star, etc.[5]

Over the years, the Ukrainians in Romania have perfected this art of passing their folklore by organizing folk festivals. These gatherings are hosted Ukrainian officials who welcome all folklore lovers to come and put on performances for the delight of the public. During these folk festivals, many folk assemblies display their knowledge, be them dances, songs, poetry, etc.

We give here only a few examples of such events where those present were given prizes for their performances: in the county of Suceava takes place the folk festival Convieţuiri (,,Співжиття "-Cohabitations). At this festival, year after year, more and more Ukrainian folk music assemblies from Bălcăuţi, Negostina, Siret, Văşcăuţi, Călineşti, Paltinu come and enrich the Ukrainian folk heritage. Such events are usually financed by the Union of the Ukrainians in Romania and the Ministry of Culture and Cults in Romania. This festival and others like it attract many professionals but, at the same time, represent a springboard, a starting point for many amateurs (the vocal assembly Cervona Kalina in Kiţimani, Cernăuţi). These interprets receive their recognition not only through prizes, but also being applauded by the spectators, who never miss the opportunity to see them and cheer the whenever such cultural events take place.

In the village of Negostina, in the county of Suceava, where almost $90 \%$ of the people are of Ukrainian origin, the Convietuiri (,, Співжиття "'-Cohabitations) festival had a very rich artistic programme, starting with a parade of folk costumes, laying flowers at the monument of Taras Şevcenko, dancing, singing performed by assemblies such as Strunele Negostinei (Negostina"s Chords), the children's fanfare and Kolomyika assembly from Siret city, the Veselka assembly from Văşcăuţi city, the vocal group Renaşterea (Resurrection) from Rădăuţi city, the Barvinok and Bukovynka assemblies, the Armonia ( Harmony) fanfare from Siret city, the vocal women's group Svekruhy in Suceava, the men's quarto and vocalist Paraska Fokşan from Snyatyn, the Peredzvin assembly from Şyşkivţi village in Cernăuţi, etc.

Other assemblies also represent the soul of such festivals: the vocal popular assembly Vyşyvanka, laureate of international prizes, artists from the Ivano-Frankivsk area, the professional duet of the regional Filarmonica in Cernăuţi, Suzir'ia - Vasyli and Tetiana Peniuk and the Mărţişor Romanian popular dance collective from the village of Voloka in Cernăuţi, the Pysanka duet -the honored artists of Ukraine O. Savciuk şi I. Kavaţiuk, the honored artist of Ukraine V. Pyndyk, the Namysto group - Nadia Nesteruk, Oxana Pavliv, Ruslana Krasiy, and many amateurs artistic assemblies from Suceava [6].

Other editions of the Convieţuiri festival have also drawn artistic representatives such as the vocal formation from Cârlibaba, the Nehostynski struny (Negostina"s chords) assembly, the Poiana Micului Polish assembly, the Veselka (Rainbow) collective from Văşcăuţi, the Svekruhy (Mothers in law) collective, Nadiia (Hope) from Suceava, the Prylypcianka women"s vocal popular amateur assembly from Prylypce village in Cernăuţi, and others, all receiving from the organizers diplomas of honor [7].

With respect and asking for forgiveness from those who, from one reason or the other, have not been mentioned, we state that we have only mentioned here a small part of the assemblies, artists or groups that take part in these events and have receive recognition far and wide.

At all these artistic events the public is not entirely made up of Ukrainians. Romanians represent a fair number, as well. This is only natural, since, despite the fact that many Ukrainians keep to themselves, marrying and establishing connections only with other Ukrainians, living in Romania mixed marriages between Ukrainians and Romanians do occur. Thus, the language and the national popular traditional culture represent the link between two peoples. Both these peoples have had their share of hardships over the ages, learning to value all the little things, to respect each other, to trust each other and to learn from each other. Respecting traditional values lead to tolerance and understanding, to acceptance, to peaceful coexistence for a mutual benefit People have learnt to look out for themselves and for their neighbors living close to them. It is more than obvious that, living near somebody, people will learn from that somebody. This process goes both ways. Old traditions were kept on both sides but, what is of great importance, new common traditions gradually appeared. These are the result of the collective way of life. Many factors lead to such an outcome, among which 
are social, political, religious and cultural factors. [7] Knowing the way the linguistic process called linguistic tracing works, one would realize that borrowings are normal, as long as they are supported by real needs. Living close to someone, witnessing their way of life, being a part of it, whether from necessity or from one's one will, people would, eventually, adopt such a way of life. After some time, it will seem natural. [8]

\section{CONCLUSIONS}

All these come as arguments in the favor of the fact that Romanians and Ukrainians lived together, learned from each other, developing common traditions and habits.[9] No one can argue that a people will come to utterly lose its national values and unity. Not even the greatest empires could rob the subjugated peoples of their national identity. This paper only states that people will learn from their neighbors and not that they will completely identify with them. And all this common ground has a limit, as well. Prowling this limit means learning, going beyond this limit means losing one's spirit.

\section{REFERENCES}

[1] P. Ion, Ukrainian settlement in the county of Maramures, in Studia Linguistica Bunyck, May 2011.

[2] A. Seiciuc, Ukrainian problem in southern Bucovina,București, 2001.

[3] P. Țugui, Bucovina. History and Culture, București, 2002.

[4] F. Bodiştean, A Theory of Literature, Second Edition., Iaşi, European Institute, 2008

[5] A. Ion, Basarabia from the Union to Integration, Cartdidact, Chişinău, 2007

[6] Ciubotă, Viorel, Nicoară, Toader, Veghes, Mikola, Horvat, Liuba (coord.), Romanian-Ukrainian Relations History and Present Times, Presa Universitară Clujana, Cluj-Napoca, Editura Muzeului Sătmărean, Satu Mare, 2007

[7] A. Cernov, "Perspectives and Missed Expectations: Romanians in Bukovina (Perspectives et espoirs ratés: les roumains du nord de la Bukovine), " in DI, 2001, vol. 6, no. 3, pp. 45-48.

[8] A. Cernov, "Romanians fron the Northern Bucovina (Ukraina): Linguistic and Cultural Perspectives," The Journal Glasul Bucovinei, November 2010

[9] G. Iacob, "Ancient Maramures Romanian Country Hearth Housing, Culture and Civilization," in Lucrările Seminarului Geografic, 1992
Viorica Banciu became a member of IERDC. Org. in September 2012. She was born in Sudrigiu, the commune of Rieni, the county of Bihor, Romania in August the $18^{\text {th }}, 1962$. She graduated high-school in 1980 at Ady Sincai, Cluj-Napoca, Romania and then attended the Faculty of Letters, Babes-Bolyai University. She graduated in 1989, becoming a teacher of English and Romanian. Viorica Banciu, doctor in philology in 2007.

She worked for a period in the pre-university education namely secondary and high-school education. Presently, she works at the University of Oradea at the Faculty of Socio-Humanistic Sciences, the Department of Sciences of Education.

Her fields of interest are English Literature, Children's Literature, Linguistics, English Language Teaching, Ethnic Studies, Gender Studies.

She published five books, her current and previous research interests are linked to education and English Language Teaching for children with special educational needs and Children's Literature studies.

Dr. Viorica Banciu became associate professor of the University of Oradea in October, the first, 2012 and she is Member of International Editorial Advisory Board of PTSE- Practice and Theory is Systems of Education, Budapest a journal specialized in education studies and also member in the following associations : Linguistic Society of Romania, Romanian Society of Applied Linguistics, ESSE (European Society for the Study of English), and IERDC. Org.

Remus Eugen Földvari is participating for the first time in such an event He was born in Beiuss, the county of Bihor, the, Romania in June the $3^{\text {rd }}$ 1976. He graduated high-school in 1994 at Liceul "Samuil Vulcan" Beiuş, Romania and then attended the Faculty of Geography and History at the University of Oradea. He graduated in 1998, becoming a teacher of Geography and History. Remus Eugen Foldvary is a PHD candidate of the University of Oradea in Geography.

He worked for a period in the pre-university education namely secondary and high-school education. Presently, he works at the Technological High-school in Dobrești, the county of Bihor.

Current and previous research interests are linked to education, geomorphology, geopolitics, history.

Bianca Dana Albut was born in $12^{\text {th }}$ of September 1981, in Stei, the county of Bihor, Romania. She graduated high-school in 2000 at Theoretical Highschool "Avram Iancu" Stei, Romania and then attended the Faculty of Socio-Humanistic Sciences, The Department of Social Assistance and Sociology ,. She graduated in 2004, becoming a clerk at the University of Oradea. She is a PHD candidate of the University of Oradea .

Her fields of interest are Sociology, Ethnic Studies, Gender Studies. 